\title{
Ecological and limnological bases for management of overgrown macrophytes: introduction to a special feature
}

\author{
Maiko Kagami $^{1,2}$ · Jun Nishihiro ${ }^{2} \cdot$ Takehito Yoshida $^{3,4}$
}

Published online: 24 December 2018

(c) The Japanese Society of Limnology 2018

Overgrown macrophytes are recognized as a major issue of the ecosystem management in many shallow and eutrophic lakes of the world. Dense vegetations often cause the problems of human usage of lakes such as boat navigation, fisheries, and tourism. Overgrowth of macrophytes also has considerable impact on ecosystem processes (Caraco et al. 2006). Oxygen is one of the major factors which change dramatically, and anoxic zones created in macrophyte beds affect not only the biogeochemical cycling including methane emission, denitrification, and phosphorus release from the sediment, but also aquatic organisms especially fish and benthos (Caraco and Cole 2002).

In past decades, cyanobacteria blooms have been a key issue in lake management rather than macrophytes (Paerl et al. 2011). In contrast to overgrown macrophytes, cyanobacteria bloom also causes toxin and odors problems for drinking waters. Excess nutrient loading, i.e., eutrophication, can cause the catastrophic regime shifts from clear water states with macrophytes dominance toward turbid states with cyanobacterial bloom (Scheffer et al. 2001). Lake restoration has been made to bring back the macrophytes, because macrophytes are known to play important roles in maintaining clear water states by suppressing phytoplankton growth and facilitating their own growth (Jeppesen et al. 2012). This sounds contradictory to the abovementioned conditions created by overgrown macrophytes. There must be critical

Maiko Kagami

mycoloop@gmail.com

1 Graduate School of Environment and Information Sciences, Yokohama National University, Yokohama, Kanagawa, Japan

2 Faculty of Sciences, Toho University, Funabashi, Chiba, Japan

3 Research Institute for Humanity and Nature, Kamigamo, Kyoto, Japan

4 Department of General Systems Studies, University of Tokyo, Komaba, Tokyo, Japan conditions when macrophytes become problematic in lakes and ponds. One important aspect is density-dependent processes. If the vegetation is not so dense, macrophytes can maintain biodiversity, water quality, and other ecosystem services. It also depends on the species and life forms of the macrophytes. Macrophytes that contribute to maintain clear water are mainly submerged macrophytes. If floating-leaved macrophytes dominate, their leaves cover the water surface as same as cyanobacteria, and the conditions created must be different from those by submerged macrophytes. If macrophytes are invasive plants, such as alligator weeds, there would be significant efforts to eliminate the plants from the ecosystems. These circumstances suggest that the management of macrophytes should be planned based on the scientific knowledge of how the macrophytes affect ecosystem processes and biodiversity in lakes and ponds.

This special issue aims to contribute to constructing the scientific bases for the macrophyte management in lakes. The special issue covered 3 topics, including (1) ecological mechanisms of the macrophyte overgrowth in shallow lakes. Kim and Joo (2018) reported that aquatic plant cover in agricultural reservoirs in Korea were influenced not only by the nutrient conditions but also by the water level, concluding that the water level should also be considered to control the overgrowth of aquatic plants. (2) The effects of macrophyte overgrowth on biotic and abiotic properties in lake ecosystems. Floating leaved plants, especially water chestnuts (Trapa species), dominate many shallow eutrophic lakes in Japan, such as Lake Inba, Lake Ohnuma and Lake Mikata. Takagi et al. (2018) and Saito et al. (2018) showed how the propagation of Trapa spp. during summer affected the habitat use and foraging of the water beetle, Galerucella nipponensis. Otake et al. (2017) found that induced defence of Brachionus calyciflorus differed between macrophyte bed and open water, which can be explained by the difference of the distributions of predators such as copepods and Asplanchna. Miyashita et al. (2018) discovered that attached or free-living bacteria associated with Trapa japonica had 
potentials to kill or inhibit the growth of cyanobacteria, such as Microcystis aeruginosa. (3) Effects of macrophyte management on the biodiversity and ecosystem processes in lakes. Verhofstad and Bakker (2017) categorized "nuisance" problems caused by submerged macrophytes, and defined that vegetation cover and canopy depth were the main determinant characters for nuisance. Ishikawa et al. (2018) proposed the optimal ranges of PVI (\% volume infestation) of the submerged plants for ecosystem management based on the relationship with DO and taxa richness of epi-fauna, epishellfish and periphyton. Kohzu et al. (2018) examined the pore water quality of the surface sediment as indicator of the effects of macrophyte harvesting on water quality and compared different harvesting methods such as cutting away and pulling up by root. Ban et al. (2018) reviewed a recycling system with anaerobic digestion of submerged macrophytes for effective utilization and sustainable management of macrophytes.

We hope that this collection of studies will stimulate further research, especially developing sustainable management of macrophytes with careful considerations of the roles of macrophytes in ecosystem processes.

We appreciate all the anonymous reviewers and the authors for their contributing to this special feature.

\section{References}

Ban S, Toda T, Koyama M, Ishikawa K, Kohzu A, Imai A (2018) Modern lake ecosystem management by sustainable harvesting and effective utilization of aquatic macrophytes. Limnology. https ://doi.org/10.1007/s10201-018-0557-z

Caraco N, Cole J (2002) Contrasting impacts of native and alien macrophyte on dissolved oxygen in a large river. Ecol Appl 12:1496-1509
Caraco N, Cole J, Findlay S, Wigand C (2006) Vascular plants as engineers of oxygen in aquatic systems. Bioscience 56:219-225

Ishikawa K, Haga H, Inoue E, Ban S (2018) Determining suitable submerged macrophyte biomass in terms of dissolved oxygen concentration and biodiversity in the South Basin of Lake Biwa, Japan. Limnology. https://doi.org/10.1007/s10201-018-0566-y

Jeppesen E, Sondergaard M, Sondergaard M, Christofferson K (eds) (2012) The structuring role of submerged macrophytes in lakes, vol 131. Springer Science \& Business Media, Berlin

Kim JY, Joo G-J (2018) Combined influence of meteorological, hydrological, and physicochemical factors on macrophyte overgrowth in agricultural reservoirs. Limnology. https://doi.org/10.1007/s1020 1-018-0550-6

Kohzu A, Shimotori K, Imai A (2018) Effects of macrophyte harvesting on the water quality and bottom environment of Lake Biwa, Japan. Limnology. https://doi.org/10.1007/s10201-018-0556-0

Miyashita Y, Hagiwara T, Imai I (2018) The existence of cyanobactericidal bacteria and growth-inhibiting bacteria on water plants in Lake Ohnuma, Japan. Limnology. https://doi.org/10.1007/s1020 1-018-0542-6

Otake Y, Kagami M, Kuriyama T, Yoshida T (2017) Spatial heterogeneity in induced defense of Brachionus calyciforus within a single lake caused by a bed of foating-leaved macrophyte Trapa species. Limnology. https://doi.org/10.1007/s10201-017-0534-y

Paerl HW, Hall NS, Calandrino ES (2011) Controlling harmful cyanobacterial blooms in a world experiencing anthropogenic and climatic-induced change. Sci Total Environ 409(10):1739-1745

Saito O, Kobayashi T, Hiroi M, Kawatsu M, Takagi S, Nishihiro J, Kagami M (2018) Seasonal changes in the biomass of floating leaved plant, Trapa spp., and its relation with a leaf beetle, Galerucella nipponensis, in Lake Inba, Japan. Limnology. https ://doi.org/10.1007/s10201-018-0554-2

Scheffer M, Carpenter S, Foley JA, Folke C, Walker B (2001) Catastrophic shifts in ecosystems. Nature 413(6856):591

Takagi S, Nakanishi N, Tanimura S, Kuriyama T, Kagami M (2018) Utilization of emergent plants as an aestivation habitat by the Trapa-feeding leaf beetle (Galerucella nipponensis) in Lake Inba, Japan. Limnology. https://doi.org/10.1007/s10201-018-0545-3

Verhofstad MJJM, Bakker ES (2017) Classifying nuisance submerged vegetation depending on ecosystem services. Limnology. https:// doi.org/10.1007/s10201-017-0525-z 